\title{
Morphological variation in Scandinavian populations of the diploid-tetraploid species pair Anthericum ramosum and Anthericum liliago (Anthericaceae)
}

\author{
Gabrielle Rosquist and Honor C. Prentice
}

\begin{abstract}
Both members of the diploid-tetraploid species pair Anthericum ramosum L. and Anthericum liliago L. occur as geographically disjunct isolates on the margins of their northern range in Scandinavia. Variation in floral morphology was studied in 33 populations of $A$. ramosum from four geographic regions and 25 populations of A. liliago from seven regions in Scandinavia. Tepal shape was characterized with the help of moment invariants, and intra- and interspecific variation in style and filament length was investigated. There were significant between-region and betweenpopulation differences in tepal shape and style and filament length within both species. However, despite the geographic disjunction of both species' distributions, there was considerable overlap in tepal shape between populations from the different regions. The hierarchical partitioning of tepal shape diversity was similar in the two species. Most of the total diversity was explained by regional and interpopulation components of diversity (48\% and 35\%, respectively, in A. ramosum and $61 \%$ and $22 \%$, respectively, in A. liliago). The two species were clearly discriminated on the basis of tepal shape and style and outer filament lengths. A southern Swedish population, containing triploid hybrids between A. ramosum and A. liliago, was indistinguishable from other Scandinavian populations of A. liliago on the basis of tepal shape. However, a (allegedly hybrid) Danish population of A. liliago was intermediate between the two species in tepal shape.
\end{abstract}

Key words: polyploidy, geographic variation, tepal shape, hybridization, moment invariants.

Résumé : Les deux membres de la paire d'espèces diploïde-tétraploïde Anthericum ramosum L. et Anthericum liliago L. existent comme isolats géographiquement disjoints à la marge de leur zone de distribution, en Scandinavie. Les auteurs ont étudié la variation de la morphologie florale dans 33 populations de l'A. ramosum provenant de quatre régions géographiques, et 25 populations de l'A. liliago provenant de sept régions, en Scandinavie. La forme des tépales se caractérise avec l'aide d'invariants momentanés (moment invariants), et on a également examiné la variation intra- et inter-spécifique de la longueur du style et des filaments. Il y a des différences significatives entre les régions et entre les populations, dans la forme des tépales et de la longueur du style et des filaments, à l'intérieur de chacune des deux espèces. Cependant, malgré la disjonction géographique des distributions des deux espèces, on observe un recouvrement considérable dans la forme des tépales entre les populations des différentes régions. La répartition hiérarchique de la diversité des formes des tépales est semblable chez les deux espèces. La majeure partie de la diversité totale s'explique par des composantes régionales et inter-populations de la diversité (48\% et 35\% chez l'A. ramosum et $61 \%$ et $22 \%$ chez l'A. liliago). Les deux espèces se distinguent nettement sur la base de la forme des tépales et des longueurs du style et des filaments. Une population du sud de la Suède, comportant des hybrides triploïdes entre l'A. ramosum et l'A. liliago, est indistincte des autres populations scandinaves de l'A. liliago, sur la base de la forme des tépales. Cependant, une population danoise (considérée comme hybride) de l'A. liliago est intermédiaire entre les deux espèces, quant à la forme des tépales.

Mots clés : polyploïdie, variation géographique, forme des tépales, hybridation, invariants momentanés.

[Traduit par la Rédaction]

\section{Introduction}

Many of the central and southern European plant species that reach their northern range limits in southern Scandinavia are restricted to open habitats and occur in a few geographically disjunct regions (Hultén 1971). It is unclear to what extent the marginal Scandinavian distributions of southern and central European species reflect the species' climatic, ecologi-

Received April 11, 2000. Published on the NRC Research Press Web site at http://cjb.nrc.ca on July 6, 2001.

G. Rosquist, ${ }^{1}$ and H.C. Prentice. Department of Systematic Botany, University of Lund, Ö. Vallgatan 14-20, S-223 61 Lund, Sweden.

${ }^{1}$ Corresponding author (e-mail: Gabrielle.Rosquist@sysbot.lu.se). 
cal, or physiological limits (Bengtsson et al. 1988). However, it is likely that the present-day distributions of many of these species have a strong historical component and are related to the postglacial availability of open sites within a predominantly forested landscape. There are notable concentrations of range-margin disjuncts in open grasslands and fissured limestone habitats on the islands of Öland and Gotland (Sterner 1922; Bengtsson et al. 1988; Ekstam et al. 1984). There are also concentrations of disjunct species in grasslands on unstable sandy soils along the southern and eastern coasts of the province of Skåne in southern Sweden (Olsson 1994).

The lilioid herbs Anthericum ramosum L. and Anthericum liliago L. (Anthericaceae (= Liliaceae s.1.)) are morphologically similar and have similar European distributions (Hultén and Fries 1986). Both the diploid A. ramosum and the tetraploid A. liliago have their northern range limits in southern Scandinavia, where each of the species occurs in a small number of geographically isolated regional populations (Hultén 1971; Hultén and Fries 1986). They are found in open grassland habitats on fissured limestone, unstable coastal or lakeside slopes, or freely drained sandy soils. Both species have been lost from many sites where they occurred earlier in the present century (e.g., Weimarck and Weimarck 1985; Wind 1993). Particularly in Denmark and southernmost Sweden, the loss of populations is a consequence of the increasing industrialization of agriculture and the associated decline in areas of traditionally grazed and unfertilized grasslands (cf. Rosquist and Prentice 2000).

The regional isolates of the two species are often geographically coincident (Hultén 1971). However, at present there are few sites where populations of the two species occur in sympatry. As has been observed in other diploidpolyploid species pairs (Thompson and Lumaret 1992), the flowering phenologies of Scandinavian A. ramosum and A. liliago are normally nonoverlapping. However, one A. liliago population in Skåne (southernmost Sweden) contains a high proportion of individuals that have a flowering time that is intermediate to that of the two species (Strandhede 1963). Phenologically intermediate individuals from this Skåne population have been shown to be triploid hybrids between $A$. ramosum and A. liliago (Strandhede 1963). A phenologically and morphologically aberrant population of $A$. liliago has also been reported from Sjælland (eastern Denmark).

In the present study of variation in floral morphology in populations of $A$. ramosum and A. liliago at the northern limits of their ranges, we investigated whether the pronounced geographic disjunction is reflected in the structuring of interpopulation differentiation within species or in the hierarchical partitioning of morphometric diversity between populations and regions. We also compared the patterns of regional differentiation within the two species and examined whether the structure of the morphometric variation in either of the species can be interpreted in terms of scenarios of postglacial immigration (Hewitt 1996; Runyeon and Prentice 1997a). We compared the sizes of the reproductive organs in the two species to determine whether there were consistent size differences that agree with the prediction that polyploids will be larger than their diploid relatives (Stebbins 1971). Finally, we evaluated the morphological affinities between the phenologically aberrant A. liliago populations on
Fig. 1. The regional distributions of Anthericum ramosum ( and Anthericum liliago $(\boldsymbol{\Delta})$ in Denmark and Sweden. Regional codes: A, Jylland; B, Sjælland; C, Halland; D, Skåne; E, Blekinge; F, Öland; G, Östergötland; H, Gotland.

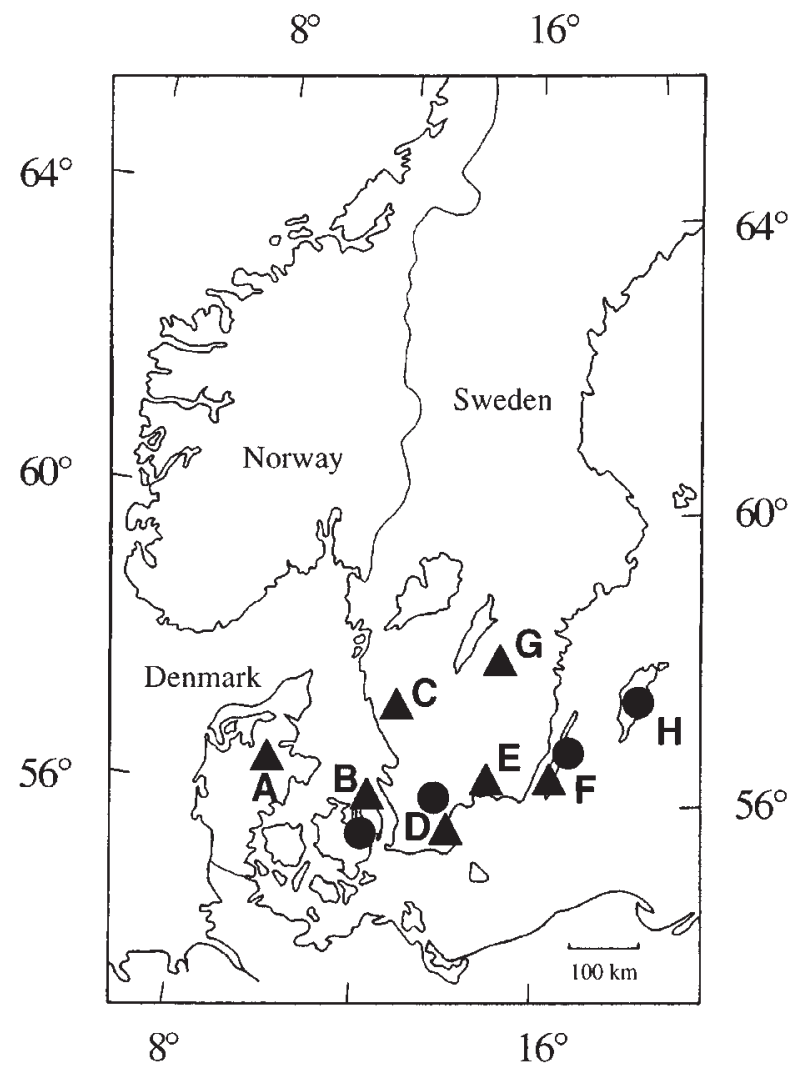

Sjælland and in Skåne and the other populations of A. liliago and $A$. ramosum. The late-flowering Skåne population of A. liliago occurs in a site where the two species are at the present day sympatric, and this population is known to contain triploid hybrids (Strandhede 1963). It has been suggested that the late flowering Sjælland A. liliago may also have a hybrid origin, although it is currently geographically isolated from other populations of both $A$. ramosum and A. liliago.

\section{Materials and methods}

\section{The species}

Anthericum ramosum and A. liliago are closely related, long-lived perennial herbs. Both species have white, diurnal flowers with six tepals arranged in two whorls of three. Anthericum ramosum is regarded as a diploid $(2 n=30,32)$ and has a branched inflorescence, while A. liliago is tetraploid $(2 n=60,64)$ in Scandinavia and usually has an unbranched inflorescence (Strandhede 1963; Tutin et al. 1980). Preliminary allozyme data suggest that A. liliago is an allotetraploid and that $A$. ramosum may be involved in its parentage (G. Rosquist and H.C. Prentice, data not shown). No other members of the genus are present in northern Europe. The mean number of flowers per inflorescence in Scandinavian material is $45(n=$ $23)$ in A. ramosum and $19(n=33)$ in A. liliago (G. Rosquist, personal observations). The flowers of $A$. liliago are larger $(35-40 \mathrm{~mm}$ in diameter) than the flowers of A. ramosum (20-26 mm in diameter) (Hegi 1909; Strandhede 1963). In Sweden, A. liliago flowers in June and A. ramosum flowers from late July to the end of August. 
Table 1. Regions, populations, population codes, estimated population sizes (total number of ramets and number of flowering ramets), sample sizes (one flower per individual), and geographic locations (latitude and longitude) for 33 populations of Anthericum ramosum (from four regions) and 25 populations of Anthericum liliago (from seven regions) in Denmark (Dk) and Sweden (Sw).

\begin{tabular}{|c|c|c|c|c|c|c|c|}
\hline \multirow[b]{2}{*}{ Species } & \multirow[b]{2}{*}{ Region } & \multirow[b]{2}{*}{ Population } & \multirow[b]{2}{*}{ Population code } & \multicolumn{2}{|c|}{ Population sizes (no. of ramets) } & \multirow[b]{2}{*}{ Sample size } & \multirow[b]{2}{*}{ Latitude, longitude } \\
\hline & & & & Total & Flowering & & \\
\hline \multirow[t]{24}{*}{ A. ramosum } & \multirow[t]{4}{*}{ Sjælland (Dk) } & Kregme Strand & KS & 1900 & 400 & 8 & $55^{\circ} 56^{\prime} \mathrm{N}, 12^{\circ} 03^{\prime} \mathrm{E}$ \\
\hline & & Frederikssund & FS & 320 & 70 & 4 & $55^{\circ} 50^{\prime} \mathrm{N}, 12^{\circ} 06^{\prime} \mathrm{E}$ \\
\hline & & Kyndbyværket & KY & 3000 & 500 & 15 & $55^{\circ} 49^{\prime} \mathrm{N}, 11^{\circ} 54^{\prime} \mathrm{E}$ \\
\hline & & Ejby Ådal & $\mathrm{E} \AA$ & 4500 & 900 & 15 & $55^{\circ} 43^{\prime} \mathrm{N}, 11^{\circ} 51^{\prime} \mathrm{E}$ \\
\hline & \multirow[t]{6}{*}{ Skåne (Sw) } & Söndre Klack 1 & SK1 & 1300 & 400 & 16 & $55^{\circ} 50^{\prime} \mathrm{N}, 14^{\circ} 04^{\prime} \mathrm{E}$ \\
\hline & & Sågmöllan 1 & SM1 & 1800 & 800 & 19 & $55^{\circ} 56^{\prime} \mathrm{N}, 14^{\circ} 05^{\prime} \mathrm{E}$ \\
\hline & & Sågmöllan 2 & SM2 & 12000 & 2000 & 12 & $55^{\circ} 56^{\prime} \mathrm{N}, 14^{\circ} 05^{\prime} \mathrm{E}$ \\
\hline & & Sågmöllan 3 & SM3 & 600 & 170 & 11 & $55^{\circ} 56^{\prime} \mathrm{N}, 14^{\circ} 04^{\prime} \mathrm{E}$ \\
\hline & & Everöd & ER & 5000 & 500 & 19 & $55^{\circ} 54^{\prime} \mathrm{N}, 14^{\circ} 06^{\prime} \mathrm{E}$ \\
\hline & & Horna & $\mathrm{HO}$ & 1100 & 400 & 18 & $55^{\circ} 57^{\prime} \mathrm{N}, 14^{\circ} 16^{\prime} \mathrm{E}$ \\
\hline & \multirow[t]{6}{*}{ Öland (Sw) } & Gynge Alvar 1 & GY1 & 25000 & 5000 & 15 & $56^{\circ} 31^{\prime} \mathrm{N}, 16^{\circ} 29^{\prime} \mathrm{E}$ \\
\hline & & Skarpa Alby 2 & SA2 & 25000 & 5000 & 15 & $56^{\circ} 35^{\prime} \mathrm{N}, 16^{\circ} 34^{\prime} \mathrm{E}$ \\
\hline & & Skarpa Alby 3 & SA3 & 1500 & 400 & 15 & $56^{\circ} 34^{\prime} \mathrm{N}, 16^{\circ} 34^{\prime} \mathrm{E}$ \\
\hline & & Vickleby 1 & VB1 & 2000 & 1000 & 15 & $56^{\circ} 34^{\prime} \mathrm{N}, 16^{\circ} 29^{\prime} \mathrm{E}$ \\
\hline & & Vickleby 2 & VB2 & 500 & 200 & 15 & $56^{\circ} 34^{\prime} \mathrm{N}, 16^{\circ} 30^{\prime} \mathrm{E}$ \\
\hline & & Vickleby 3 & VB3 & 14000 & 1200 & 14 & $56^{\circ} 33^{\prime} \mathrm{N}, 16^{\circ} 30^{\prime} \mathrm{E}$ \\
\hline & \multirow{8}{*}{ Gotland (Sw) } & Hejdeby 1 & $\mathrm{HB} 1$ & 12000 & 2000 & 15 & $57^{\circ} 38^{\prime} \mathrm{N}, 18^{\circ} 23^{\prime} \mathrm{E}$ \\
\hline & & Hejdeby 2 & HB2 & 10000 & 2000 & 15 & $57^{\circ} 37^{\prime} \mathrm{N}, 18^{\circ} 25^{\prime} \mathrm{E}$ \\
\hline & & Hejdeby 3 & HB3 & 100000 & 3000 & 15 & $57^{\circ} 38^{\prime} \mathrm{N}, 18^{\circ} 24^{\prime} \mathrm{E}$ \\
\hline & & Etelhem 1 & EH1 & 4500 & 1000 & 11 & $57^{\circ} 19^{\prime} \mathrm{N}, 18^{\circ} 31^{\prime} \mathrm{E}$ \\
\hline & & Etelhem 2 & $\mathrm{EH} 2$ & 6500 & 1500 & 15 & $57^{\circ} 19^{\prime} \mathrm{N}, 18^{\circ} 31^{\prime} \mathrm{E}$ \\
\hline & & Etelhem 3 & $\mathrm{EH} 3$ & 3500 & 400 & 13 & $57^{\circ} 20^{\prime} \mathrm{N}, 18^{\circ} 31^{\prime} \mathrm{E}$ \\
\hline & & Sundre 1 & SE1 & 9000 & 2000 & 15 & $56^{\circ} 56^{\prime} \mathrm{N}, 18^{\circ} 11^{\prime} \mathrm{E}$ \\
\hline & & Sundre 2 & SE2 & 500000 & 50000 & 15 & $56^{\circ} 56^{\prime} \mathrm{N}, 18^{\circ} 10^{\prime} \mathrm{E}$ \\
\hline \multirow{18}{*}{ A. liliago } & \multirow{8}{*}{ Skåne (Sw) } & Vitemölla & $\mathrm{VM}$ & 300000 & 100000 & 20 & $55^{\circ} 42^{\prime} \mathrm{N}, 14^{\circ} 12^{\prime} \mathrm{E}$ \\
\hline & & Haväng & $\mathrm{HA}$ & 250 & 110 & 6 & $55^{\circ} 43^{\prime} \mathrm{N}, 14^{\circ} 11^{\prime} \mathrm{E}$ \\
\hline & & Brösarps N. Backar & BNB & 550 & 50 & 8 & $55^{\circ} 43^{\prime} \mathrm{N}, 14^{\circ} 04^{\prime} \mathrm{E}$ \\
\hline & & Drakamölla & DM & 150 & 22 & 5 & $55^{\circ} 45^{\prime} \mathrm{N}, 14^{\circ} 08^{\prime} \mathrm{E}$ \\
\hline & & Maglehem & $\mathrm{MH}$ & 3000 & 900 & 20 & $55^{\circ} 46^{\prime} \mathrm{N}, 14^{\circ} 08^{\prime} \mathrm{E}$ \\
\hline & & Degeberga & $\mathrm{DB}$ & 900 & 150 & 17 & $55^{\circ} 50^{\prime} \mathrm{N}, 14^{\circ} 05^{\prime} \mathrm{E}$ \\
\hline & & Stora Drivan & SD & 550 & 150 & 17 & $55^{\circ} 51^{\prime} \mathrm{N}, 14^{\circ} 10^{\prime} \mathrm{E}$ \\
\hline & & S. Lyngsjön & LY & 100 & 10 & 2 & $55^{\circ} 55^{\prime} \mathrm{N}, 14^{\circ} 04^{\prime} \mathrm{E}$ \\
\hline & Blekinge (Sw) & Hoka Gård & $\mathrm{HG}$ & 500 & 180 & 17 & $56^{\circ} 17^{\prime} \mathrm{N}, 14^{\circ} 51^{\prime} \mathrm{E}$ \\
\hline & \multirow[t]{8}{*}{ Öland (Sw) } & Penåsa & $\mathrm{PE}$ & 600 & 50 & 6 & $56^{\circ} 26^{\prime} \mathrm{N}, 16^{\circ} 28^{\prime} \mathrm{E}$ \\
\hline & & Millersten & MS & 550 & 70 & 16 & $56^{\circ} 26^{\prime} \mathrm{N}, 16^{\circ} 30^{\prime} \mathrm{E}$ \\
\hline & & Penåsabäcken & $\mathrm{PB}$ & 1100 & 300 & 15 & $56^{\circ} 26^{\prime} \mathrm{N}, 16^{\circ} 30^{\prime} \mathrm{E}$ \\
\hline & & Ammatornsrör & $\mathrm{AR}$ & 1900 & 400 & 11 & $56^{\circ} 26^{\prime} \mathrm{N}, 16^{\circ} 30^{\prime} \mathrm{E}$ \\
\hline & & N. Ammatornsrör & NAR & 2500 & 750 & 16 & $56^{\circ} 27^{\prime} \mathrm{N}, 16^{\circ} 30^{\prime} \mathrm{E}$ \\
\hline & & Gösslunda & GL & 1800 & 400 & 10 & $56^{\circ} 29^{\prime} \mathrm{N}, 16^{\circ} 31^{\prime} \mathrm{E}$ \\
\hline & & Ismantorp & IT & 600 & 70 & 6 & $56^{\circ} 45^{\prime} \mathrm{N}, 16^{\circ} 37^{\prime} \mathrm{E}$ \\
\hline & & Noaks Ark & NA & 1500 & 400 & 18 & $56^{\circ} 46^{\prime} \mathrm{N}, 16^{\circ} 37^{\prime} \mathrm{E}$ \\
\hline & Östergötland (Sw) & Somvik & SV & 200000 & 40000 & 24 & $58^{\circ} 04^{\prime} \mathrm{N}, 15^{\circ} 11^{\prime} \mathrm{E}$ \\
\hline
\end{tabular}

Both species are insect pollinated and self-compatible (Rosquist 2001). The fruits are loculicidal capsules and the seeds lack specialized dispersal mechanisms (Rosquist 2001). Triploid hybrids
$(2 n=3 \times=44,45)$ have been reported from one site in Skåne (southern Sweden) in an area where the two species co-occur at present (Strandhede 1963). Hybrid individuals have a flowering 
time (late June to mid July) that is intermediate to that of A. ramosum and A. liliago (Strandhede 1963).

The geographic distributions of both Anthericum species are centred in central Europe, with marginal, northern populations in southern Scandinavia (maps in Hultén and Fries 1986). Within Scandinavia, both species have populations on Sjælland (Denmark) and in Skåne, on Öland and on Gotland (Sweden). Anthericum liliago also occurs in Jylland and on Fyn (Denmark) and in Halland, Blekinge, and Östergötland (Sweden). The two species are rare and occur in scattered populations in northern Germany and Poland, but they are more frequent in central Europe (Hultén and Fries 1986). In Scandinavia, both species grow in dry grasslands on steep slopes or (on the islands of Öland and Gotland) in areas with fissured limestone.

\section{Sites and sampling}

Whole flowers for morphometric analysis were sampled from 33 populations of $A$. ramosum within four geographic regions and from 25 populations of $A$. liliago within seven regions (Fig. 1; Table 1). Totals of 475 and 320 individuals were sampled from $A$. ramosum and A. liliago, respectively, during the period 1995-1997 (Table 1). Within regions, populations of A. ramosum were separated from each other by 0.1 to $80.0 \mathrm{~km}($ mean $=17.4 \mathrm{~km})$. The local geographic distribution of $A$. liliago populations within Scandinavia is even more restricted than that of $A$. ramosum. The sampled populations of A. liliago were separated from each other by 0.2 to $38.2 \mathrm{~km}$ $($ mean $=14.3 \mathrm{~km})$ within regions. For each species, we sampled one flower per individual from 15-20 individuals per population. Populations of $A$. ramosum and A. liliago may be spatially restricted but contain many densely grouped ramets. Within populations, the sampled (flowering) individuals were separated from each other by at least $5 \mathrm{~m}$ to avoid sampling from closely related individuals. The restricted spatial extent, small size, or low number of flowering individuals in some populations, especially of A. liliago, meant that some of the sample sizes were less than 15 (Table 1). Triploid hybrids between A. ramosum and A. liliago have been previously reported from the Degeberga (DB) population of A. liliago in Skåne (Strandhede 1963). When sampling material from DB for the present investigation, we focussed on individuals with intermediate flowering phenology (presumed hybrids).

Permission to sample flowers from Denmark, where both species are nationally protected, was obtained from the Forest and $\mathrm{Na}-$ ture Board (Skov- og Naturstyrelsen) at the Danish Ministry for Environment and Energy. Permission to sample A. liliago flowers from Skåne and Blekinge in Sweden, where the species is also protected, was obtained from the regional governments in the provinces of Kristianstad (now Skåne) and Blekinge.

\section{Tepal shape}

Totals of 461 and 320 individuals were scored for tepal shape in A. ramosum and A. liliago, respectively. The three (in a few cases two or four) freshly sampled inner tepals from each flower were pressed and their outlines were captured by a video camera and transferred to a computer via an analogue-to-digital converter. The shape of each tepal was then described with the help of moment invariants (Dudani et al. 1977; White et al. 1988). The image acquisition and shape description was carried out with the program ARBO 1.74 (White et al. 1988).

\section{Style and filament length}

Where possible, style and filament lengths were measured with a calibrated ocular micrometer on the same flowers that were scored for tepal shape. Totals of 466 and 319 individuals were scored for style and filament length in A. ramosum and A. liliago, respectively. The style and the six stamens from each sampled flower were mounted while fresh under a strip of Scotch magic tape on a glass
Fig. 2. Between-population differentiation in tepal shape in 33 populations of Anthericum ramosum based on a CVA of moment invariants. In the CVA, the groups were populations and the within-group replicates were individuals (mean values of three (2-4) inner tepals from one flower). The first and second CVs account for $51 \%$ and $19 \%$, respectively, of the total betweenpopulation variance. Regional codes: $\square$, Sjælland; $\bigcirc$, Skåne; $\bullet$ Öland; $\mathbf{\square}$, Gotland. Population codes (cf. Table 1) are given for the populations that are discussed in the text.

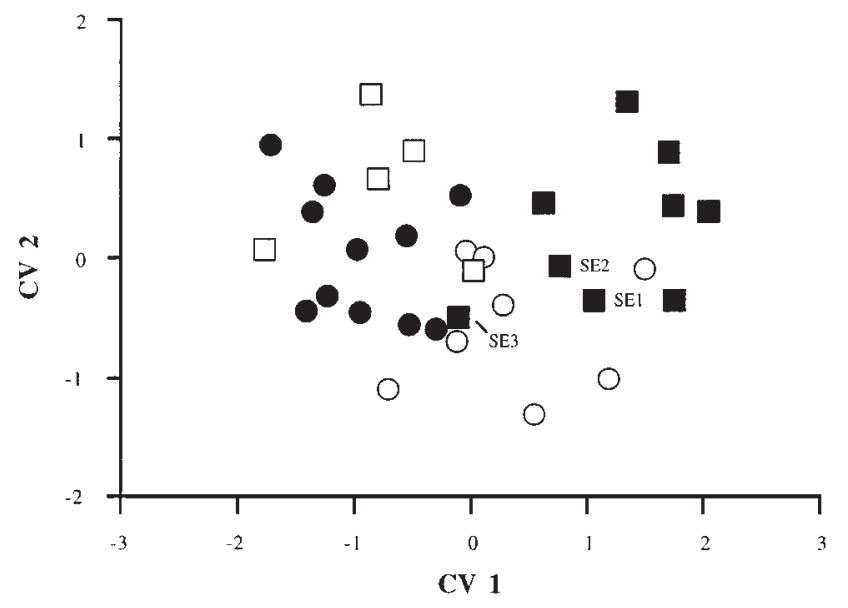

slide. The six stamens within a flower are arranged in two whorls of three, and we calculated the mean lengths of the three inner and the three outer filaments for each flower. We also measured the length of the style (including the stigma) for each flower.

\section{Data analysis}

\section{Patterns of morphological differentiation between populations and species}

Patterns of between-population differentiation in tepal shape were analysed in three separate canonical variates analyses (CVAs), based on the 33 populations of $A$. ramosum, the 25 populations of A. liliago, and the pooled data (58 populations) from both species. The CVAs were based on the populations as groups, with individuals as within-group replicates. Each individual was represented by the mean values of the inner tepals from one flower. The analyses were carried out using the routine CANDISC in the software package from SAS Institute Inc. (1996).

\section{The partitioning of tepal shape diversity}

Wilks' $\Lambda$ statistics from a series of CVAs were used to partition tepal shape diversity into its within- and between-region and -population components within each of the species (White and Prentice 1988; Runyeon and Prentice 1997b). Wilks' $\Lambda$ gives the proportion of the total diversity that is due to within-group diversity in CVA. Two CVAs were carried out for the partition analyses in each of the species. In these analyses, the within-group replicates were individuals (mean data from 3 (2-4) tepals of one flower) and the groups were defined as regions (analysis $\mathrm{R}$ ) or populations (analysis P) giving, respectively, $\Lambda_{R}$ and $\Lambda_{\mathrm{P}}$. Within each species, $1-\Lambda_{R}$ gives the between-region component of the total morphological diversity and $\Lambda_{R}-\Lambda_{P}$ gives the between-population component of the total diversity. The within-population diversity is given by $\Lambda_{\mathrm{P}}$.

\section{Styles and filaments}

Differences in style length and outer and inner filament lengths between populations, regions, and species were tested with oneway analyses of variance (ANOVA), followed by multiple 
Table 2. Mantel tests for associations between matrices of Mahalanobis' distances (MORPH, based on tepal shape) and matrices of geographic distances (GEO) and Rogers' genetic distances (GEN, based on allele frequencies at nine polymorphic loci; for Anthericum ramosum only) for 33 populations of A. ramosum and 25 populations of Anthericum liliago from Denmark and Sweden.

\begin{tabular}{llllll}
\hline & \multicolumn{2}{l}{ Anthericum } & ramosum & & \multicolumn{2}{l}{ Anthericum liliago } \\
\cline { 2 - 3 } Pairwise matrix comparisons & $r$ & & & $r$ & $P$ \\
\hline MORPH $\times$ GEN & 0.326 & $0.001^{* * * *}$ & & - & - \\
MORPH $\times$ GEO & 0.232 & $0.002^{* *}$ & & 0.009 & $0.386 \mathrm{~ns}$ \\
MORPH $\times$ GEO (TB excluded) & - & - & & 0.050 & $0.271 \mathrm{~ns}$ \\
MORPH $\times$ GEO (TB and DB excluded) & - & - & & 0.046 & $0.295 \mathrm{~ns}$ \\
\hline
\end{tabular}

Note: Matrix correlation coefficient (r) and one-tailed probability with $>2000$ permutations. ns, nonsignificant.

$* * P<0.01$.

$* * * P<0.001$

comparisions of means (based on Tukey's method for groups with unequal sample sizes). The statistical analyses of style and filament lengths were carried out with the program package STATISTICA (StatSoft Inc. 1994).

\section{Comparision of distance matrices}

For each species, the matrix of between-population Mahalanobis' distances (derived from the CVA analyses with populations as groups) for tepal shape was compared with the matrix of geographic distances between populations, using the generalized regression method of Mantel (Mantel 1967), based on a bootstrapping procedure with 2000 permutations. For A. ramosum, we also compared the matrices of morphometric and geographic distances with a matrix of genetic distances (Rogers' genetic distances based on within-population allozyme frequencies at nine polymorphic loci) derived from the same 33 populations that were included in the present study (Rosquist and Prentice 2000). The matrix comparisions were carried out with the program NTSYS-pc (Rohlf 1994).

\section{Results}

\section{Patterns of differentiation and the partitioning of diversity within $A$. ramosum}

\section{Differentiation in tepal shape between populations within}

A. ramosum

The first two canonical variates (CVs) from a CVA of 33 populations of $A$. ramosum, based on moment invariant descriptors of tepal shape, are shown in Fig. 2. There is no clear separation of the populations in the four regions (Sjælland, Skåne, Öland, and Gotland). However, on CV1, all but one (SE3) of the Gotland populations are separated from the Öland and the Sjælland populations. There is also a tendency for the Skåne populations to be separated from the Sjælland populations by lower scores on CV2.

There was a positive association between the matrices of geographic distance and Mahalanobis' distance (based on tepal shape) between populations of A. ramosum (Mantel test, $P=0.002$; Table 2). A positive association (Mantel test, $P=0.001$; Table 2) was also found between the matrix of Mahalanobis' distances and a matrix of Rogers' genetic distances based on allozyme data (Rosquist and Prentice 2000).

\section{Differentiation in style and filament length within}

\section{A. ramosum}

The lengths of the styles and the inner and outer filaments differ significantly $(P<0.001$, in all analyses $)$ be- tween the $33 A$. ramosum populations $\left(F_{[32,434]}=14.97\right.$, $F_{[32,434]}=11.91$, and $F_{[32,434]}=8.07$, from the ANOVAs for style, inner filament, and outer filament lengths, respectively) and between the four regions $\left(F_{[3,463]}=82.65\right.$, $F_{[3,463]}=70.92$, and $F_{[3,463]}=50.39$, for style, inner filament, and outer filament lengths, respectively). The mean values and the standard errors for style, inner filament, and outer filament lengths of $A$. ramosum flowers for the four regions (Sjælland, Skåne, Öland, and Gotland) are shown in Fig. 3. The Gotland individuals have significantly longer styles $(14.79 \pm 0.174 \mathrm{~mm})$ and inner and outer filaments $(11.32 \pm 0.121$ and $8.19 \pm 0.082 \mathrm{~mm}$, respectively) than individuals from the other three regions (Sjælland (13.15 \pm $0.216,9.78 \pm 0.165$, and $7.30 \pm 0.133 \mathrm{~mm}$, respectively), Skåne $(13.53 \pm 0.142,9.71 \pm 0.115$, and $7.53 \pm 0.085 \mathrm{~mm}$, respectively), and Öland (11.79 $\pm 0.105,9.23 \pm 0.088$, and $6.90 \pm 0.062 \mathrm{~mm}$, respectively)). The Gotland population SE3 differs significantly for all three characters (in the multiple comparison test of 33 populations) from the rest of the Gotland populations, but is not significantly different from the populations from Sjælland, Skåne, and Öland. Öland individuals have significantly shorter styles than individuals from the other three regions (Sjælland, Skåne, and Gotland) and shorter inner and outer filaments than those from Skåne. There were no significant differences in style or filament lengths between individuals from Sjælland and Skåne.

Partitioning of diversity in tepal shape within A. ramosum

Most $(48 \%)$ of the total diversity in tepal shape within A. ramosum was accounted for by the between-regional component of variation (Table 3), 35\% of the total diversity is due to variation between populations within regions, and $16 \%$ is due to variation between individuals within populations.

\section{Patterns of differentiation and the partitioning of diversity within $A$. liliago}

\section{Differentiation in tepal shape between populations within A. liliago}

The first two CVs from the CVA of the 25 populations of A. liliago, based on the moment invariant descriptors of tepal shape, are shown in Fig. 4. As in A. ramosum, there is no clear regional grouping of populations. The single population from Sjælland (TB) forms an outlier, with a low score on CV2. The Blekinge population (HG) has high scores on 
CV1, while the populations from Jylland (HD), Halland (SS), and Östergötland (SV) are grouped together with the Öland and Skåne populations. The Skåne populations form a loose group on the right of the figure and the Öland populations are grouped on the left of the figure. The hybrid population DB (Skåne) is grouped together with the Öland populations on the left of the figure.

In contrast with $A$. ramosum, there was no positive association between the matrices of geographic and tepal shape distances, even when the outlying Sjælland (TB) population or both the $\mathrm{TB}$ and the hybrid Skåne $(\mathrm{DB})$ populations were excluded from the matrix comparisons (Mantel test; Table 2).

\section{Differentiation in style and filament length within}

\section{A. liliago}

There were significant differences $(P<0.001$, in all analyses) in the lengths of the styles and the inner and outer filaments between the 24 A. liliago populations $\left(F_{[23,278]}=12.5\right.$, $F_{[23,278]}=9.6$, and $F_{[23,278]}=9.1$, from the ANOVAs for style, inner filament, and outer filament lengths, respectively) and the 7 regions $\left(F_{[6,295]}=24.2, F_{[6,295]}=16.4\right.$, and $F_{[6,295]}=10.0$, for style, inner filament, and outer filament lengths, respectively) when the hybrid Skåne (DB) population was excluded. If the DB population was included in the analyses, significant differences were also found between the 25 populations and seven regions $(P<0.001$, in all analyses). The mean values and the standard errors for style lengths and outer and inner filament lengths for A. liliago flowers from the seven regions (Jylland, Sjælland, Halland, Skåne, Blekinge, Öland, and Östergötland) and for the hybrid population (DB) are shown in Fig. 5. Anthericum liliago individuals from Östergötland have the highest mean values of style $(15.54 \pm 0.411 \mathrm{~mm})$ and outer and inner filament lengths $(9.91 \pm 0.185$ and $8.33 \pm 0.147 \mathrm{~mm}$, respectively) of the seven regions (Fig. 5). Skåne material has significantly longer styles $(14.54 \pm 0.155 \mathrm{~mm})$ and outer filaments $(9.21 \pm 0.109 \mathrm{~mm})$ than Öland material $(12.26 \pm 0.141$ and $8.15 \pm 0.086 \mathrm{~mm}$, respectively), and Öland has the lowest mean values for style length of all the regions. Individuals in the hybrid DB population only differed from the other Skåne individuals in mean style length $(12.70 \pm 0.393 \mathrm{~mm})$.

\section{Partitioning of diversity in tepal shape within A. liliago}

The partitioning of tepal shape diversity in A. liliago was based on data from 24 populations (excluding the hybrid population DB). As in A. ramosum, most of the total diversity in tepal shape within A. liliago was accounted for by the between-regional component of variation (Table 3 ). The partitioning of the total morphological variation in A. liliago gave a regional diversity component of $61 \%$ and a betweenpopulation component of $22 \%$. Seventeen percent of the diversity was accounted for by diversity between individuals within populations.

\section{Patterns of morphological differentiation between the two species}

Differentiation in tepal shape between A. ramosum and A. liliago

The first two CVs of the tepal shape CVA based on the pooled population data from A. ramosum and A. liliago are
Fig. 3. Between-region differences for 33 populations of Anthericum ramomsum in (A) mean style length, (B) mean outer filament length, and $(\mathrm{C})$ mean inner filament length. Standard errors are indicated by bars. Pairs of regions that are not significantly different (one-way ANOVAs) are indicated by the same letters. Regional codes: Sj, Sjælland; Sk, Skåne; Öl, Öland; Go, Gotland.
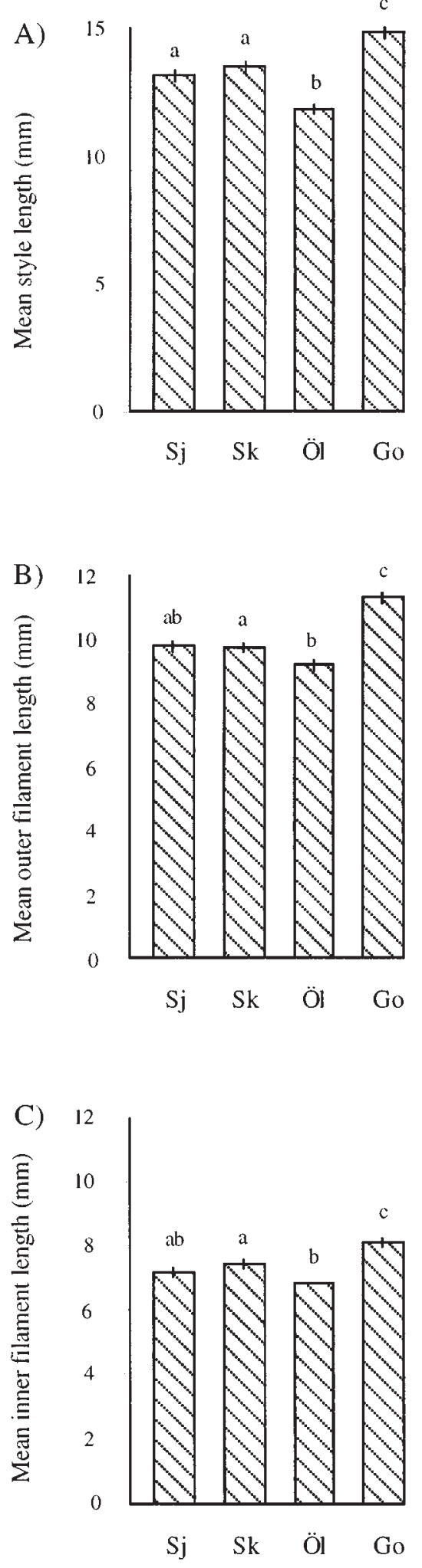

(C) 2001 NRC Canada 
Table 3. The hierarchical partitioning of tepal shape diversity in Anthericum ramosum and Anthericum liliago and statistics from canonical variates analyses based on individuals as withingroup replicates and regions or populations as groups.

\begin{tabular}{|c|c|c|}
\hline & Anthericum ramosum & Anthericum liliago \\
\hline No. of populations & 33 & 24 \\
\hline No. of descriptors & 7 & 7 \\
\hline \multicolumn{3}{|l|}{ Significant $(5 \%)$ descriptors } \\
\hline Regions as groups (analysis R) & 7 & 5 \\
\hline Populations as groups (analysis P) & 7 & 7 \\
\hline \multicolumn{3}{|l|}{ Regions as groups (analysis $\mathbf{R}$ ) } \\
\hline No. of axes significant at $5 \%$ & 3 & 2 \\
\hline No. of axes extracted & 3 & 6 \\
\hline \multicolumn{3}{|l|}{ Populations as groups (analysis P) } \\
\hline No. of axes significant at $5 \%$ & 4 & 3 \\
\hline No. of axes extracted & 7 & 7 \\
\hline \multicolumn{3}{|l|}{ Wilks' $\Lambda$} \\
\hline Regions as groups, analysis $R\left(\Lambda_{R}\right)$ & $0.5185^{* * *}$ & $0.3896 * * *$ \\
\hline Populations as groups, analysis $\mathrm{P}\left(\Lambda_{\mathrm{P}}\right)$ & $0.1645 * * *$ & $0.1704 * * *$ \\
\hline \multicolumn{3}{|l|}{ Partitioning of the total tepal shape diversity } \\
\hline Between regions $\left(1-\Lambda_{R}\right)$ & 0.482 & 0.610 \\
\hline Between populations within regions $\left(\Lambda_{R}-\Lambda_{P}\right)$ & 0.354 & 0.219 \\
\hline Between individuals within populations $\left(\Lambda_{P}\right)$ & 0.164 & 0.170 \\
\hline
\end{tabular}

Note: The total diversity in tepal shape is partitioned into its within- and between-region and -population components for A. ramosum and A. liliago (see the text for further details). The hybrid Skåne population (DB) is excluded from the A. liliago analysis.

$* * * P<0.001$

Fig. 4. Between-population differentiation in tepal shape in 25 populations of Anthericum liliago based on a CVA of moment invariants. In the CVA, the groups were populations and the within-group replicates were individuals (mean values of three (2-4) inner tepals from one flower). The first and second CVs account for $49 \%$ and $24 \%$, respectively, of the total betweenpopulation variance. Regional codes: $\square$, Jylland; $\square$, Sjælland; $\boldsymbol{O}$, Halland; $\bigcirc$, Skåne; $\triangle$, Blekinge ; $\boldsymbol{\bullet}$, Öland; $\boldsymbol{\Delta}$, Östergötland. Population codes (cf. Table 1) are given for the populations that are discussed in the text. A hybrid population between Anthericum ramosum and A. liliago DB (Skåne) is included in the analysis.

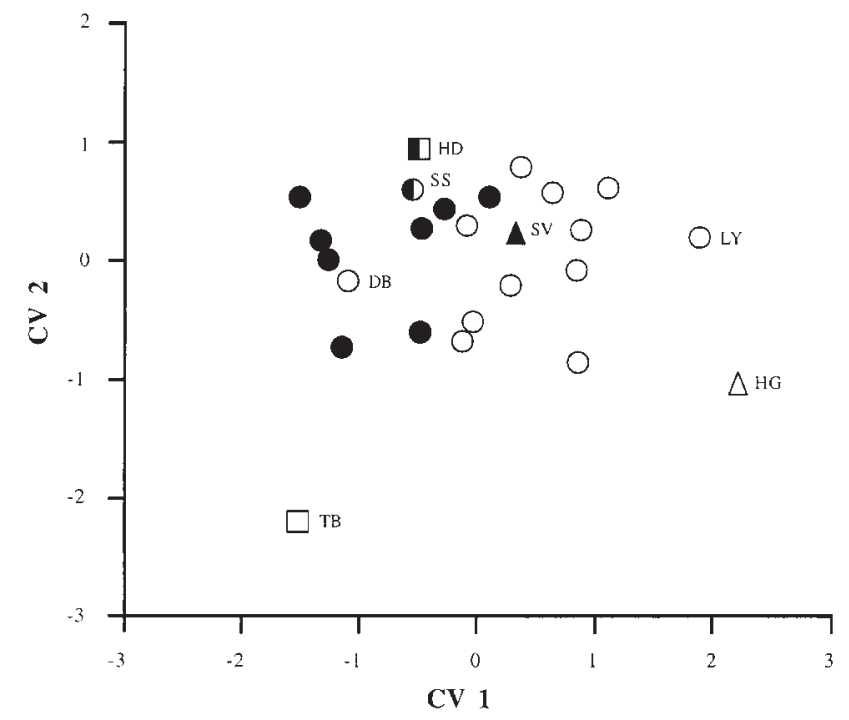

shown in Fig. 6. The populations of A. ramosum and A. liliago are clearly separated, with all 33 populations of A. ramosum grouped on the left of the figure and 23 of the 25 populations of $A$. liliago grouped on the right of the figure. Two A. liliago populations fall outside the main group of A. liliago populations. Population TB (Sjælland) is positioned between the groups of $A$. ramosum and $A$. liliago populations, and population LY (Skåne) is an outlier to the group of A. liliago populations on the far right of the figure.

Figure 7 is based on the CVA in Fig. 6, but with each population represented by one, randomly chosen tepal from one individual. The tepals of $A$. ramosum are smaller and broader in relation to their length than the A. liliago tepals. The tepal from the outlying A. liliago Sjælland population (TB) is intermediate in size and shape between the two species.

Interspecific comparisons of style and inner and outer filament lengths show that $A$. liliago has significantly longer styles $\left(F_{[1,756]}=12.53, P<0.001\right)$ than $A$. ramosum, while $A$. ramosum has significantly longer outer filaments $\left(F_{[1,756]}=132.32, P<0.001\right)$. There were no significant differences in inner filament lengths between the two species.

\section{Discussion}

\section{Differentiation and diversity within $A$. ramosum: tepal shape and allozymes}

The pattern of differentiation in A. ramosum tepal shape is more continuous and shows a less distinct regional structure than the mosaic pattern that was detected in an earlier study of allozyme variation in the same set of populations (Rosquist and Prentice 2000). Neither the earlier allozyme study nor the present investigation of floral morphology in A. ramosum reveal patterns of regional differentiation that 
can be easily interpreted in terms of scenarios of postglacial immigration. However, allozyme frequency data do suggest that the populations from northern and southern Gotland may have had separate historical origins (Rosquist and Prentice 2000).

Allozyme data often reveal a more discrete structure of geographic differentiation than morphological characters (e.g., Allen et al. 1995; Lönn and Prentice 1995), and Lewontin (1984) provides a general explanation of why morphological characters (controlled by several or many loci) may be expected to detect a more subtle pattern of population differentiation than single-locus characters. In addition, in studies such as the present investigation of tepal shape based on morphological phenotypes, patterns of differentiation will reflect both environmental and genetic components of variation. Thus, it is more likely that environmentally related variation will be detected in phenotypic characters than in single-locus characters, such as allozymes, that are under direct genetic control.

Despite the fact that there is a somewhat overlapping pattern of regional differentiation in tepal shape in A. ramosum, the hierarchical analysis of tepal shape diversity showed that the between-region component of diversity accounted for the majority of the total diversity (Table 3 ). Only $16 \%$ of the total diversity was accounted for by the within-population component of diversity. In contrast, the hierarchical partition of allozyme diversity showed a between-regional component of $13 \%$ and a within-population component of $75 \%$ (Rosquist and Prentice 2000). Studies that compare patterns of variation and the structure of diversity in allozyme and morphometric characters show that geographic pattern is not necessarily a good predictor of the structure of genetic diversity, and that there is not necessarily a correspondence between the diversity partitions reflected in morphological and allozyme characters. Several studies show that the rank ordering of the diversity partition may be similar between different sets of characters, regardless of whether the characters show different patterns of geographic differentiation (e.g., Schwaegerle et al. 1986; Prentice and Andersson 1997). However, other studies support the present comparison of allozymes and tepal shape of $A$. ramosum, where allozymes tend to show a relatively large within-population and a relatively low between-population (or between-region) component of diversity compared with that shown in morphological characters (e.g., Prentice 1992; Runyeon and Prentice 1997b).

\section{Morphological differentiation and diversity within \\ A. liliago: comparison with $A$. ramosum}

Anthericum liliago has an even more fragmented and disjunct Scandinavian distribution than A. ramosum (Hultén 1971). The two regions (Skåne and Öland) that have the highest concentration of populations (which are represented by several populations in our investigation) form loose and intergrading groups in the analysis of tepal shape (Fig. 4) and the pattern of between-population differentiation is more or less continuous. The hybrid Skåne population (DB) is separated from the rest of the Skåne populations and falls within the main group of the Öland populations. The LY population (Skåne), which forms an outlier in the ordination, was only represented by data from two individuals. However, the HG population from Blekinge and the TB popula-
Fig. 5. Between-region differences for 25 populations of Anthericum liliago in (A) mean style length, (B) mean outer filament length, and (C) mean inner filament length. Standard errors are indicated by bars. Pairs of regions that are not significantly different (one-way ANOVAs) are indicated by the same letters. Regional codes: Jy, Jylland; Sj, Sjælland; Ha, Halland; Sk, Skåne; Bl, Blekinge; Öl, Öland; Ög, Östergötland. Population codes are given where a region is represented by a single population. The hybrid population DB (Skåne) is treated as a separate "region."
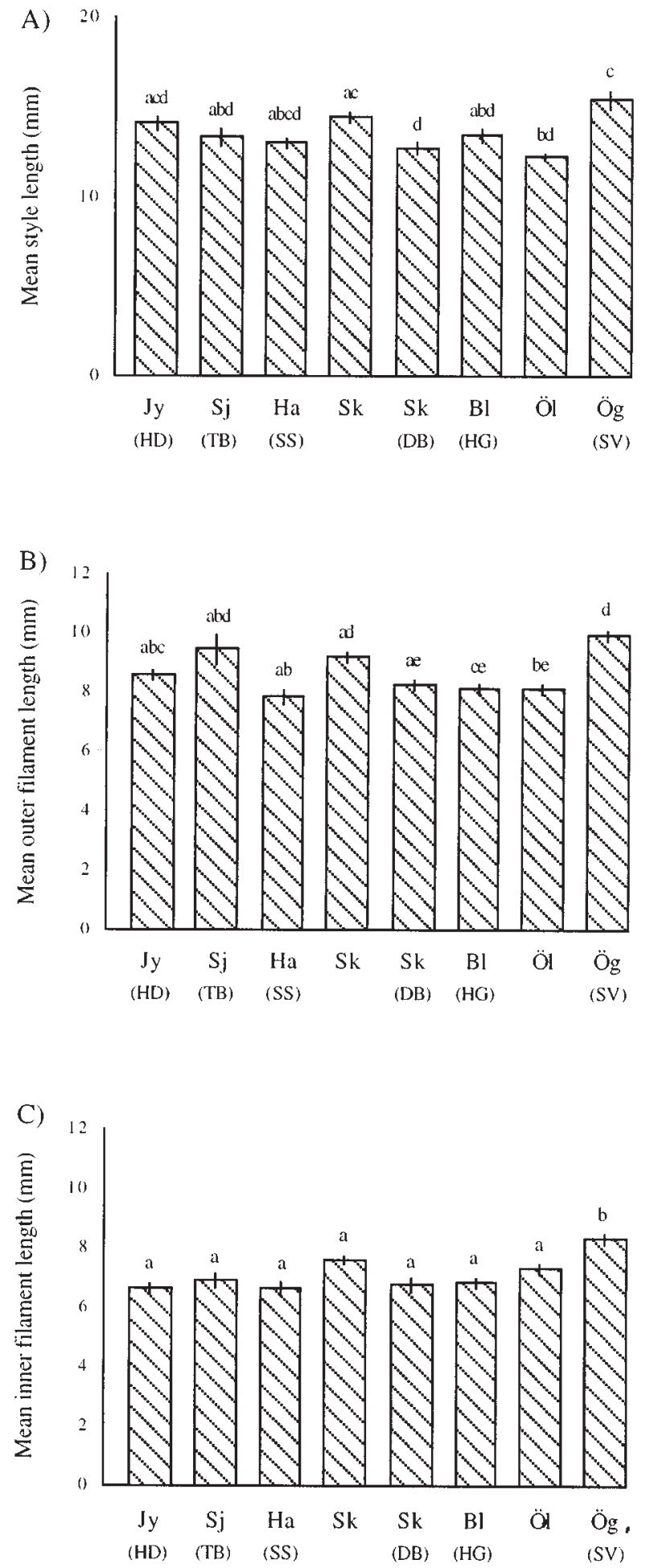
Fig. 6. Between-population differentiation in tepal shape in 58 populations of Anthericum ramosum and Anthericum liliago based on a CVA of moment invariants. In the CVA, the groups were populations and the within-group replicates were individuals (mean values of three (2-4) inner tepals from one flower). The first and second CVs account for $89 \%$ and 5\%, respectively, of the total between-population variance. Regional codes: ( $\mathbf{\square}$, Jylland; $\square$, Sjælland; $\bigcirc$, Halland; $\bigcirc$, Skåne; $\triangle$, Blekinge ; $\bullet$, Öland; $\boldsymbol{\square}$, Gotland; $\boldsymbol{\Delta}$, Östergötland. Population codes (cf. Table 1) are given for the populations that are discussed in the text. A hybrid population between A. ramosum and A. liliago DB (Skåne) is included in the analysis.

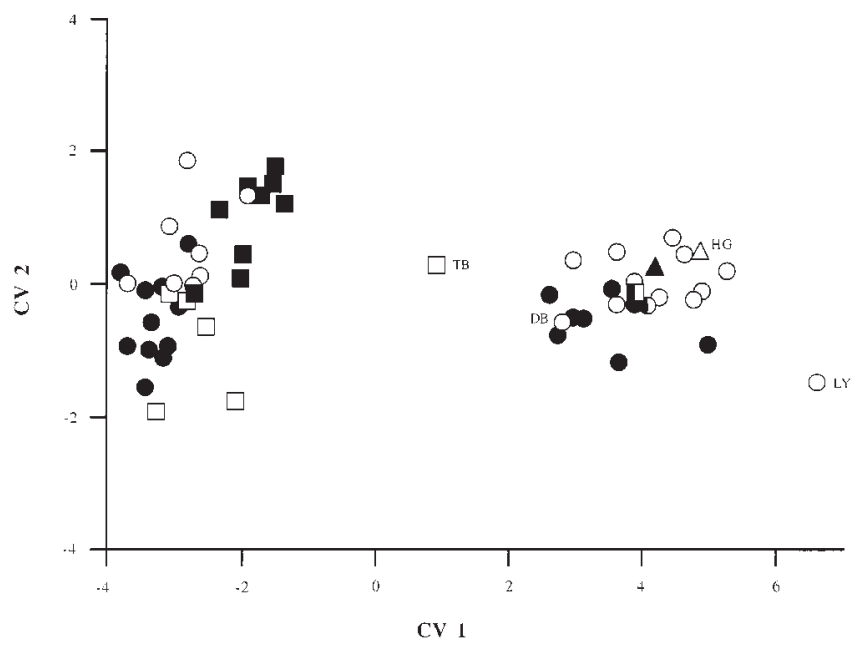

tion from Sjælland, which occupy clearly outlying positions in relation to the rest of the populations, are both large and represented by data from ca. 15 flowering individuals (Table 1). The geographically isolated populations SV, HD, and SS (see Fig. 1 and Table 1) are not separated from the main group of populations on the basis of tepal morphology, and there is no overall tendency for populations from adjacent geographic regions to form large-scale geographic groups. In contrast with $A$. ramosum, there was no significant association between geographic and morphological distances (even after the removal of the outlier TB and the hybrid DB population). But the sampling design in A. ramosum included several populations within each of the regions, whereas most regions in A. liliago are only represented by one or two populations.

The hierarchical structure of tepal shape diversity within A. liliago was similar to that in A. ramosum, with the majority of the total diversity (61\%, compared with $48 \%$ in A. ramosum) explained by the between-region component of diversity and a relatively low within-population component of diversity (17\%, compared with $16 \%$ in A. ramosum). The high regional component of diversity in both species is consistent with their strongly disjunct regional distributions in Scandinavia.

\section{Morphological relationships between $A$. ramosum and A. liliago}

Populations of $A$. ramosum and A. liliago form two discrete and well-separated groups on the basis of tepal shape (Figs. 6 and 7). Tepal shape provided a reliable character for discriminating between the two species and the tetraploid A. liliago also has larger tepals than diploid A. ramosum
Fig. 7. Tepal shape variation in Anthericum ramosum and Anthericum liliago. One randomly chosen tepal from each population is superimposed on the CVA of the between-population differentiation in tepal shape (moment invariants) for the 58 populations of A. ramosum and A. liliago in Fig. 6. A hybrid population between $A$. ramosum and $A$. liliago DB (Skåne) is included in the analysis.

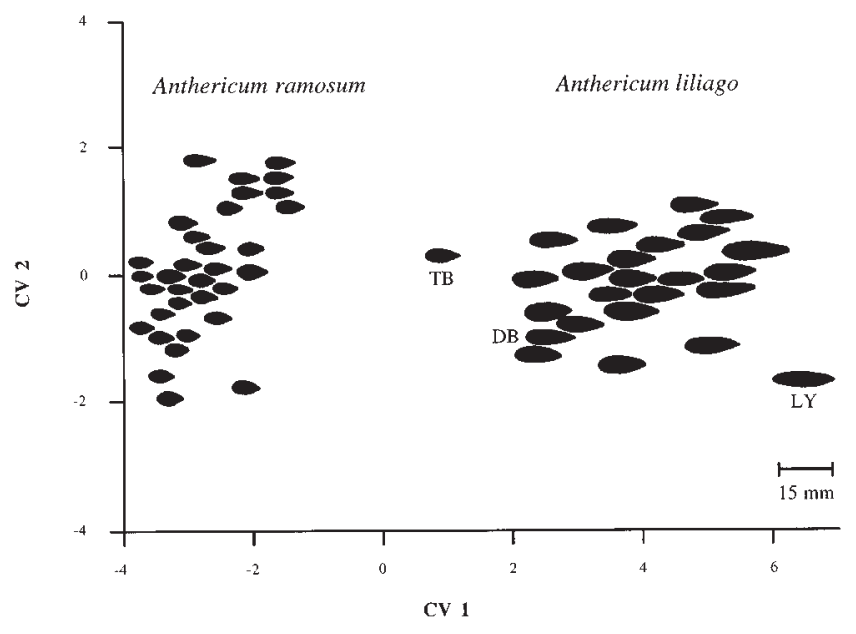

(Fig. 7; Strandhede 1963). It has been suggested that because genome size is related to cell size, polyploids are, in general, expected to be larger than related diploid taxa (Stebbins 1971), and many studies have reported larger sizes of plants, inflorescences, flowers, and pollen grains in polyploid compared with diploid taxa (e.g., Phlox drummondii (Garbutt and Bazzaz 1983), Asphodelous fistulosus (Ruiz Rejón et al. 1990), Vaccinium uliginosum (Jacquemart and Thompson 1996), Arrhenatherum elatius (Petit and Thompson 1997), and Lotus corniculatus (Gauthier et al. 1998)). In Anthericum, although the tepals are larger and the styles longer in the tetraploid (A. liliago) than in the diploid (A. ramosum), the lengths of the outer filaments are significantly longer in the diploid than in the tetraploid. Consequently, the relative lengths of tepals, styles, and filaments differ between the two species. The styles in the diploid (A. ramosum) protrude beyond the relatively short tepals, resulting in species-specific differences in the presentation of anthers and stigmas to visiting insects.

Polyploidization may be associated with changes in guilds of pollinating insects (Segraves and Thompson 1999). Selection by pollinators influences local and regional differentiation in floral morphology within species (Galen 1996; Johnson and Steiner 1997). The fact that the Öland populations of both species have the shortest styles and filaments suggests that there may be regional differences in the guilds of pollinators that visit both $A$. ramosum and A. liliago. It is reasonable to expect that selection by pollinators has contributed to the patterns of inter- and intra-specific differences in floral morphology in A. ramosum and A. liliago. Both species are visited by bumble bees, honey bees, and syrphids (G. Rosquist, personal observations). However, we have no detailed information on the species' pollination biology.

Polyploidization may be accompanied by a shift in flowering phenology (e.g., Thompson and Lumaret 1992). It has been suggested that a delay in the flowering season of a 
polyploid in relation to its diploid progenitor would be expected if cell division and growth rates are slower in polyploids than in diploids (Stebbins 1971). Most studies of phenology in diploid-tetraploid pairs of taxa have been made on autopolyploids (A. liliago is thought to have had an allopolyploid origin (G. Rosquist and H.C. Prentice, data not shown)). In Phlox drummondii (Garbutt and Bazzaz 1983) and Plantago media (van Dijk et al. 1992) the polyploid cytotypes have been shown to flower later than the diploid cytotypes. However, in Arrhenatherum elatius (Petit et al. 1997) and Dactylis glomerata (Lumaret et al. 1987), as in Anthericum, the polyploids flower earlier than the diploids.

The A. liliago population TB (from Sjælland), which was an outlier in the A. liliago tepal shape ordination (Fig. 4), occupies a position between the groups of $A$. ramosum and A. liliago populations in the pooled-species ordination (Fig. 7). Danish botanists have also observed that this population is morphologically intermediate between $A$. ramosum and A. liliago and that it's time of flowering is intermediate between the two species (S.E. Sandermann Olsen and F. Skovgaard, personal communication). The fruit set of individuals in the TB population is said to be low, and it has been suggested that this population may represent a hybrid between $A$. ramosum and $A$. liliago. However, there are no other populations of A. liliago on Sjælland at the present day and the nearest $A$. ramosum population is about $114 \mathrm{~km}$ distant. Cytological data from Sjælland individuals are needed to clarify the status of the TB population.

In contrast with the TB population (Sjælland), the DB (Skåne) population of $A$. liliago, which has been shown to contain triploid hybrid individuals (Strandhede 1963), has a similar tepal shape to other A. liliago populations, although it is distinct from other Skåne populations (Fig. 4). Hybrids within the DB population have been reported as being female sterile (Strandhede 1963; G. Rosquist, personal observation) but male fertile with $10 \%$ to $50 \%$ morphologically well-developed pollen grains (Strandhede 1963). The ability of the hybrids to produce some fertile pollen may allow gene flow, across ploidy levels, between the two species. Gene flow between ploidy levels is usually unidirectional, from $2 \times$ to $3 \times$ to $4 \times$ (Levin 1978). The site where the DB population occurs is one of the few Scandinavian localities that currently contains both $A$. ramosum and $A$. liliago individuals. The hybrid individuals in the DB population have a flowering time that is intermediate between the early flowering A. liliago and the later flowering A. ramosum. There are recent reports of other late-flowering A. liliago individuals or populations from Skåne (K.A. Olsson, personal communication; G. Rosquist, personal observation) and from Öland (Ålind and Öberg 1999). It is possible that these individuals or populations may also contain hybrids, particularly in the northern part of Skåne and on Öland, where populations of the two species show a limited degree of sympatry.

\section{Acknowledgements}

We thank Sven-Erik Sandermann Olsen, Finn Skovgaard, Peter Wind, and Hans Øllgaard for help in locating the Danish sites and Jan-Thomas Johansson, Kjell-Arne Olsson, Ingvar Lenfors, Åke Widgren, and Dan Nilsson for help with the sites in Skåne, Halland, Blekinge, and Östergötland.
Martin Stjernman assisted with the fieldwork in Denmark and on Gotland, and Ingrid Larsson helped with the measurement of flowers. We are grateful to John D. Thompson for constructive criticism of an earlier version of the manuscript. The Uppsala University Ecological Station at Ölands Skogsby was used as a base for fieldwork on the Öland and Östergötland material. The study was funded by grants to $\mathrm{G}$. Rosquist from P.F. Wahlbergs minnesfond, Axel Hallströms donation, and Dagny and Eilert Ekvalls premie- och stipendiefond and by a grant to H.C. Prentice from SJFR (the Swedish Forestry and Agricultural Research Council).

\section{References}

Ålind, P., and Öberg, E. 1999. Den stora sandliljans Anthericum liliago förekomst på Öland. Krutbrännaren, 8: 75-83.

Allen, G.A., Antos, J.A., Worley, A.C., Suttill, T.A., and Hebda, R.J. 1995. Morphological and genetic variation of the avalanche lily Erythronium montanum. Can. J. Bot. 74: 403-412.

Bengtsson, K., Prentice, H.C., Rosén, E., Moberg, R., and Sjögren, E. 1988. The dry alvar grasslands of Öland: ecological amplitudes of plant species in relation to vegetation composition. Acta Phytogeogr. Suec. 76: 21-46.

Dudani, S.A., Breeding, K.J., and McGhee, R.B. 1977. Aircraft identification by moment invariants. IEEE (Inst. Electr. Electron Eng.) Trans. Comput. C26: 39-45.

Ekstam, U., Jacobson, R. Mattson, M., and Porsne, T. 1984. Ölands och Gotlands växtvärld. Bokförlaget Natur och Kultur, Stockholm.

Galen, C. 1996. Rates of floral evolution: adaptation to bumblebee pollination in an alpine wildflower, Polemonium viscosum. Evolution, 50: 120-125.

Garbutt, K., and Bazzaz, F.A. 1983. Leaf demography, flower production and biomass of diploid and tetraploid populations of Phlox drummondii Hook. on a soil moisture gradient. New Phytol. 93: 129-141.

Gauthier, P., Lumaret, R., and Bedecarrats, A. 1998. Genetic variation and gene flow in alpine diploid and tetraploid populations of Lotus (L. alpinus (D.C.) Schleicher / L. corniculatus L.). 1. Insights from morphological and allozyme markers. Heredity, 80: 683-693.

Hegi, G. 1909. Illustrierte Flora von Mitteleuropa. JF Lehmann's Verlag, München.

Hewitt, G.M. 1996. Some genetic consequences of ice ages, and their role in divergence and speciation. Biol. J. Linn. Soc. 58: 247-276.

Hultén, E. 1971. Atlas över växternas utbredning i Norden. Generalstabens Litografiska Anstalts Förlag, Stockholm.

Hultén, E., and Fries, M. 1986. Atlas of north European vascular plants north of the Tropic of Cancer. Koeltz Scientific Books, Königstein.

Jacquemart, A.-L., and Thompson, J.D. 1996. Floral and pollination biology of three sympatric Vaccinium (Ericaceae) species in the Upper Ardennes, Belgium. Can. J. Bot. 74: 210-221.

Johnson, S.D., and Steiner, K.E. 1997. Pollination and evolution of floral spur length in the Disa draconis complex (Orchidaceae). Evolution, 51: 45-53.

Levin, D.A. 1978. The origin of isolating mechanisms in flowering plants. Evol. Biol. 11: 185-317.

Lewontin, R.C. 1984. Detecting population differences in quantitative characters as opposed to gene frequencies. Am. Nat. 123: 115-124. 
Lönn, M., and Prentice, H.C. 1995. The structure of allozyme and leaf shape variation in isolated, range-margin populations of the shrub Hippocrepis emerus. Ecography, 18: 276-285.

Lumaret, R., Guillerm, J-L., Delay, J., Ait Lhaj Loufti, A., Izco, J., and Jay, M. 1987. Polyploidy and habitat differentiation in Dactylis glomerata L. from Galicia (Spain). Oecologia, 73: 436-446.

Mantel, N. 1967. The detection of disease clustering and a generalized regression approach. Cancer Res. 27: 209-220.

Olsson, K-A. 1994. Sandstäpp i Skåne - ett upprop. Lunds Botaniska Förening, 2: 4-13.

Petit, C., and Thompson, J.D. 1997. Variation in phenotypic response to light availability between diploid and tetraploid populations of the perennial grass Arrhenatherum elatius from open and woodland sites. J. Ecol. 85: 657-667.

Petit, C., Lesbros, P., Ge, X., and Thompson, J.D. 1997. Variation in flowering phenology and selfing rate across a contact zone between diploid and tetraploid Arrhenatherum elatius (Poaceae). Heredity, 79: 31-40.

Prentice, H.C. 1992. The structure of morphometric and allozyme variation in relict populations of Gypsophila fastigiata in Sweden. Biol. J. Linn. Soc. 47: 197-216.

Prentice, H.C., and Andersson, S. 1997. Genetic variation and population size in the rare dioecious plant Silene diclinis (Caryophyllaceae). In The role of genetics in conserving small populations. Edited by T.E. Tew, T.J. Crawford, J.W. Spencer, D.P. Stevens, M.B. Usher, and J. Warren. Joint Nature Conservation Committee (JNCC), Peterborough, U.K. pp. 65-72.

Rohlf, F.J. 1994. NTSYS-pc. Numerical taxonomy and multivariate analysis system. Version 1.80. Exeter Software, New York.

Rosquist, G. 2001. Reproductive biology in diploid Anthericum ramosum and tetraploid $A$. liliago (Anthericaceae). Oikos, 92: $143-152$.

Rosquist, G., and Prentice, H.C. 2000. Habitat fragmentation and the structure of genetic diversity within disjunct isolates of Anthericum ramosum L. (Anthericaceae) in Scandinavia. Biol. J. Linn. Soc. 69: 193-212.

Ruiz Rejón, C., Blanca, G., Cueto, M., Lozano, R., and Ruiz Rejón, M. 1990. Asphodelus tenuifolius and A. fistulosus (Liliaceae) are morphologically, genetically, and biologically different species. Plant Syst. Evol. 169: 1-12.

Runyeon, H., and Prentice, H.C. 1997a. Genetic differentiation in the bladder campions, Silene vulgaris and S. uniflora (Caryophyllaceae), in Sweden. Biol. J. Linn. Soc. 61: 559-584.

Runyeon, H., and Prentice, H.C. 1997b. Patterns of seed polymorphism and allozyme variation in the bladder campions, Silene vulgaris and Silene uniflora (Caryophyllaceae). Can. J. Bot. 75: 1868-1886.

SAS Institute Inc. 1996. Release 6.09. SAS Institute Inc., Cary, N.C.

Schwaegerle, K.E., Garbutt, K., and Bazzaz, F.A. 1986. Differentiation among nine populations of Phlox. 1. Electrophoretic and quantitative variation. Evolution, 40: 506-517.

Segraves, K.A., and Thompson, J.N. 1999. Plant polyploidy and pollination: floral traits and insect visits to diploid and tetraploid Heuchera grossulariifolia. Evolution, 53: 1114-1127.

StatSoft Inc. 1994. STATISTICA for the Macintosh. Tulsa, Okla.

Stebbins, G.L. 1971. Chromosomal evolution in higher plants. Edward Arnold (Publishers) Ltd, London.

Sterner, R. 1922. The continental element in the flora of South Sweden. Geografiska Annaler, 4: 221-444.

Strandhede, S. 1963. Kromosomtal och morfologi hos skånsk Anthericum. Bot. Not. 116: 215-221.

Thompson, J.D., and Lumaret, R. 1992. The evolutionary dynamics of polyploid plants: origins, establishment and persistence. Trends Ecol. Evol. 7: 302-307.

Tutin, T.G., Heywood, V.H., Burges, N.A., Moore, D.M., Valentine, D.H., Walters, S.M., and Webb, D.A. 1980. Flora Europea. Vol. 5. Alismataceae to Orchidaceae (Monocotyledones). Cambridge University Press, Cambridge.

van Dijk, P., Hartog, M., and van Delden, W. 1992. Single cytotype areas in autopolyploid Plantago media L. Biol. J. Linn. Soc. 46: $315-331$.

Weimarck, H., and Weimarck, G. 1985. Atlas över Skånes Flora. Bibliotekstjänst Datafilm, Lund.

White, R.J., and Prentice, H.C. 1988. Comparision of shape description methods for biological outlines. In Classification and related methods of data analysis. Edited by H.H. Bock. Elsevier Science Publishers, Amsterdam, Netherlands. pp. 395-402.

White, R.J., Prentice, H.C., and Verwijst, T. 1988. Automated image acquisition and morphometric description. Can. J. Bot. 66: 450-459.

Wind, P. 1993. Fredede arter i Danmark 5. Urt, 2: 58-63. 